\title{
The Effectiveness of Using Jigsaw II Technique in Teaching Reading Comprehension to the Tenth Grades Students of SMK Negeri 1 Gombong in the Academic Year of 2019/2020
}

\author{
Endah Mitsalina ${ }^{a}$, Hellaisna Nur'Aini Garwan ${ }^{b}$, Rissa Filyang ${ }^{c}$ \\ ${ }^{a, b, c}$ English Education Study Program, University of Ma'arif Nahdlatul Ulama \\ Kebumen, Indonesia
}

Email of corresponding author (missentami@gmail.com)

\begin{abstract}
This research aims (1) to find out a significant difference in teaching reading comprehension between students who learned using the Jigsaw II technique and those who did not. (2) To find out the extent to which Jigsaw II technique used in teaching reading comprehension to the tenth-grade students of SMK N 1 Gombong to be effective. This research was experimental research. The research design used the pre-test-posttest control and experimental class. The population in this study was $\mathrm{X}$ grade students of SMK Negeri 1 Gombong. Sampling used a random sampling technique with the results of $\mathrm{X}$ TKJ $\mathrm{C}$ as an experimental class and $\mathrm{X}$ TKR $\mathrm{C}$ as a control class. Data collected with pre-test and post-test given to the experimental class and the control class. The validity used content validity and construct validity. Content validity carried out by expert judgment. The construct validity has done with the help of the Pearson program. The instrument reliability test conducted using split-half in the SPSS program and a value of 0.889 was obtained. The data analysis technique used the Mann Whitney test with a significance level of 5\%. The results of testing the requirements analysis showed that the pre-test and post-score scores were not normally distributed and homogeneous. The results of the study can be concluded as follows: first, there is a significant difference in reading comprehension skills between experimental class that got learning using Jigsaw II techniques and control class that got learning without using Jigsaw II techniques in $\mathrm{X}$ grade students of SMK Negeri 1 Gombong. It can be proven from the results of the Mann Whitney test post-test control class and the experimental class were obtained by Asymp Sig =0,000. Secondly, the Jigsaw II technique has been proven effective to improve reading comprehension of the X grade students of SMK Negeri 1 Gombong. It can be proven from the calculation results of the experimental class Gain Score of 23.78 and the control class 6.11.
\end{abstract}

Keywords: Effectiveness, Jigsaw II technique, Reading Comprehension

\section{INTRODUCTION}

In learning English, there are four skills, namely listening, speaking, writing, and reading. Each individual has different levels of difficulty, including difficulties in communicating, understanding grammar, or lack of vocabulary. According to Mitsalina and Pamungkas (2021: 25), the X grade students of SMK did not participate actively 
during teaching and learning process. the students were not interest to speak English. The students only listened teacher's explanation, wrote, and did an exercise or task.

Problems above are actually not due to the learner's mistakes, but it could be a mistake in the learning method that is neither attractive nor too rigid. Therefore, effective learning activities are needed. In learning English, students must be able to master four skills. The skills students to learn about how to pronounce words, write sentences grammatically and listen to foreign language sounds carefully so that what is heard is in accordance with what is said.

In line with the development of students' language ability levels, reading skill occupy an important position in the context of coaching and developing English. Through good and correct reading activities students will take the essence of the reading they read. The more essence students get, the more knowledge students get. With a lot of knowledge, students will more easily reach success.

According to Nunan (2003: 68), reading is a fluent process of readers combining information from a text and their own background knowledge to build meaning. Based on Grabe and Stoller (2011: 3), reading is the ability to draw meaning from the printed page and interpret this information appropriately. From the text the reader can get the meaning of it. In addition, they can interpret what the writer shows in the text.

According to Grabe and Stoller (2011: 5-8) the aims of reading are; 1) reading to search for simple information, 2) reading to skim quickly, 3) reading to learn from texts 4) reading to integrate information, 5) reading to write (or search for information needed for writing) and critique texts, and 6) reading for general comprehension.

Vocabulary mastery is the strongest component in reading comprehension (Harvey, 2013: 4). If the vocabulary mastery ability is owned by students, students are going to get better grades. Vocabulary mastery has a function to develop and broaden the basis of reading in students. The process of mastering vocabulary in students begins with the introduction of mother tongue. In line with the development of age, vocabulary is obtained in the environment and formal education through the teaching and learning process. Good vocabulary mastery allows one to more understand in reading without experiencing obstacles.

In the education, the activity and reading assignment are something that is not negotiable (Nurgiyantoro, 2013: 368). Reading as one of the language skills that less desirable by students. Even many students do not like to read at all. Until now, students still think that reading is a burdened for them. It is feared that the use of strategies and procedures that are less appropriate in reading learning will make students more reluctant to read.

In addition to these problems there are still many problems that arise in reading learning in schools. Data from Analytical and Capacity Development Partnership (ACDP, 2016) states, "Indonesia is one of 12 countries with significantly low scores below 
international standard referring to progress in International Reading Literacy Study (PIRLS)". Reading learning that takes place in schools so far is still using the old learning methods. The teacher still uses learning methods that are not innovative yet, so that reading learning takes place is boring. The English teachers still using lecture, discussion and assignment methods. Thus, most of the students when asked to read are only able to reach a low level of understanding.

Reading learning in schools aims to foster and improve reading skills and train students to master aspects of reading skills. Furthermore, reading comprehension requires the teacher's knowledge and skills. The use of inappropriate approaches, methods, techniques, and reading media are assumed to be one of the determinants of less-thanoptimal achievement of reading goals at school.

One technique that can help students' understanding in reading comprehension is the Jigsaw II technique. The Jigsaw II technique is a modification of the Jigsaw technique. There are learning differences in the Jigsaw and Jigsaw II technique. In the Jigsaw technique, students only learn the material that they get. Assessments on Jigsaw technique center on individual scores while assessments on Jigsaw II technique center on group scores (Slavin, 1980: 320-321).

According to Brown (2001: 185) jigsaw technique is a special form of information gap in which each member of a group is given some specific information and the goal is to pool all information to achieve some objective.

Based on Slavin (1980: 330) jigsaw is the cooperative learning technique, which used the most structured form of team interaction. Jigsaw reading is a kind of jigsaw technique which combines the idea of jigsaw puzzle with reading. The technique of jigsaw reading focuses on reading activity. Slavin (1980: 320) in Jigsaw II added, students all read the same material but focus on separate topics. The students from different teams who have the same topics meet to discuss their topics, and then return to teach them to their teammates. The team members then take a quiz, and the quiz scores are used to form team scores.

Shaaban (2006: 379) said that "The Jigsaw II technique is included in cooperative learning because Jigsaw II teaches reading comprehension with a narrative or expository material". It can be assumed Jigsaw II's technique includes cooperative learning strategies that make it easy for students to receive information from their own friends. In order to Jigsaw II technique learning run smoothly, the teacher must work closely with students to solve problems and reach mutual agreement. This technique will be tested for the effectiveness by researcher on reading learning comprehension.

The implementation of the Jigsaw II technique will be carried out at SMK N 1 Gombong, because it will be a new variation for learning process in this school. In addition, the use of this technique is intended also to create a new learning atmosphere that previously only used the lecture and assignment methods. The students should be cooperative with other to reach goal. It would train the students to work as a team in the 
learning process. It will be interesting for students. The use of this technique is also to find out whether this technique is effectively used in reading learning comprehension or not.

Based on the description above, this study was conducted to determine the use of Jigsaw II technique for reading comprehension.

\section{METHODOLOGY}

This research has been done by quantitative methods. Sugiyono (2010: 13) quantitative method is called the traditional method, because this method has been used long enough so that it has been transmitted as a method for research. This method called quantitative method because the research data in the form of numbers and analysis using statistics.

This research has been done at SMK Negeri 1 Gombong which is located at Jalan Wilis No. 15, Wero, Gombong District, Kebumen Regency. This school has been chosen by researcher to conduct research so that the methods in the learning process can be even more varied, namely with this technique.

The sampling technique used a random sampling technique. The samples in this study were classes that randomly selected from the population. This sample was taken randomly by drawing all tenth grade in SMK Negeri 1 Gombong and taking two classes. After the drawing, class X TKJC was selected as an experiment class with 36 students and class X TKROC as a control class with 36 students. Then one class was chosen as the instrument test class. From the drawing results, it was obtained that class $\mathrm{X}$ TPB as an instrument test class with 36 students.

Data collecting technique in this study has been done through tests. The test used a reading comprehension ability test. The test given to the control class and the experimental class was in the form of pre-test and post-test. Pre-test done before the experimental stage, while post-test done after the experimental stage. Pre-test used to see the students' initial abilities, while post-test is used to see their final reading comprehension.

The validity that uses in this study is the content validity and construct validity. The content validity test aims to find out the relevance research instruments with subject matter. Content validity test carried out by experts' judgment is the English teacher at SMK Negeri 1 Gombong, Dra. Dwi Estiti, the construct validity test aims to determine the suitability of the instrument research with lattice questions that are tested. The research instrument is a multiple choice totalling 30 questions. To test the validity of the questions, the instrument was tested on 36 students of class X TPB of SMK Negeri 1 Gombong outside the study sample.

The instrument reliability test is carried out to find out a consistency internal. The instrument can be said to be reliable if it shows consistent results from time to time. The instrument reliability test in this study is use with internal consistency. 


\section{FINDING AND DISCUSSION}

\section{A. Finding}

The research was conducted in the tenth grade of SMK Negeri 1 Gombong in the academic year of 2019/2020. The purposes of the research were to find out the significant difference in teaching reading comprehension between students who learned using Jigsaw II technique and those who did not. In addition, to find out the extent to which Jigsaw II technique used in teaching reading comprehension at the tenth-grade students of SMK N 1 Gombong to be effective. The data in this research include the initial test score data and the final test score data. Initial test score data was obtained from the pre-test of reading comprehension and the final test score data was obtained from the post test of reading comprehension. The data of the results of research in the control class and experiment class are presented as follows;

\section{Description of Pre-test Score of Reading Comprehension in Experiment Class}

Based on the results of the pre-test reading comprehension in the experiment class was obtained the highest score is 76 and the lowest score is 48 . The average score of the experiment class pre-test is 62.11; with a median of 62.00; mode 64 and standard deviation 7.123. The standard error pre-test in the teaching reading comprehension of the experiment class is 1,187; variant 50,730; range 28 with a total of 2236 .

\section{Description Post-Test Score of Reading Comprehension in Experiment Class}

Based on the results of the experiment class post-test obtained the highest score of 96 and the lowest score was 76. The average post-test score of the experiment class was 85.89; with a median of 86.00; mode 84 and standard deviation 5.013. The standard error in teaching reading comprehension of the experiment class is 0.835 ; variant 25,130 ; range of 20 with a total of 3092 .

\section{Description of Pre-test Score of Reading Comprehension in Control Class}

Based on the results of the pre-test reading comprehension of control class obtained the highest score is 76 and the lowest score is 44 . The average score of the pre-test control class was 64.22; with the median is 68.00; mode 68 and standard deviation 9.463. The standard error of pre- test in reading comprehension of the control class is 1557; variant 89,549 ; range 32 with the number 2312 .

\section{Description of Post-Test Score of Reading Comprehension in the Control Class}

Based on the results of the control class post-test obtained the highest score of 80 and the lowest score was 56 . The average score of the control class post-test was 70.33 ; with a median of 72.00; mode 72 and standard deviation of 5,270. The standard error in teaching reading comprehension of the control class is 0.878 ; variant 27,771 ; range 24 with the number 2532 . 


\section{Comparison of Pre-test and Post-test Score in the Control Class and Experiment Class}

The Data of pre-test of the control class, the highest score was 76, the lowest score was 44, while at the post-test the highest score was 80 and the lowest score was 56. The average score of the pre-test and post-test of the control class had changed. Control class when in the pre-test had average 64.22 while the average post-test score was 70.33. Furthermore, at the pre-test in teaching reading comprehension of the experiment class, the highest score was 76 and the lowest score was 48, while at the post-test the highest score was 96 and the lowest score was 76 . The average score of the pre-test and post-test experiment class changes become more than the control class. The average pre-test score of the experiment class is 62.11 and the average post-test score is 85.89.

\section{Validity}

In this study the instrument must be tested first to the advisor and English teachers at the research site to find out whether the instructor is appropriate to retrieve data in this study.

Validity aims to measure the extent to which the instrument measures what it wants to measure. Sugiyono (2010: 173) A valid instrument means the measuring instrument used to obtain data (measuring) is valid.

The items used for data collection consisting of 30 questions, there are 25 items declared valid and 5 items declared invalid or said not to be used in research for data collection.

\section{Reliability}

As a second requirement of data collection instruments is reliability. Sugiyono (2010: 173) A reliable instrument is an instrument that, if used several times to measure the same object, will produce the same data. In this study the reliability test was conducted with a split-half test from Spearman Brown with the help of the SPSS version 16 for windows program.

The Guttman Split-Half Coefficient in this study is 0.889. Fraenkel, Wallen \& Hyun in Yusup (2018: 21) said "An instrument is said to be reliable when the Spearman-Brown reliability coefficient value is more than 0.70 ". So, this instrument that has been tested for reliability is declared reliable.

\section{B. Discussion}

\section{The Differences in Teaching Reading Comprehension of the Experiment Class and Control Class}

The control class and the experimental classes were given a pre-test before the treatment of Jigsaw II technique be implemented. After the pre-test, the control class and the experimental class follow the learning activities of reading comprehension. The control 
class follows learning reading comprehension without using the Jigsaw II technique, while the experiment class uses the Jigsaw II technique. Based on the learning activities carried out, there are differences in activities between the control class students and the experiment class. After the reading comprehension learning activity had finished, and then it was done after reading comprehension of the control class and the experiment class. Post-test was conducted to determine whether there are differences in teaching reading comprehension of the control class and the experiment class after following a different learning process. Learning reading comprehension in the experiment class is carried out in accordance with the technical steps in Jigsaw II.

Jigsaw II technique start with reading activities. Students read the reading material to identify material that is relevant to the topic they are getting. After reading, students who have the same question form a group of experts to discuss the results of the question. Students can ask the teacher for help if you have difficulties during the discussion. After discussing with the expert group, students return to the original group to report the results of the discussion to the expert group. Each student gives and teaches material that has been obtained to his classmates. Finally, each group member is tested according to the order in the reading material. Each individual score is combined into a group score. In the process of learning reading comprehension using Jigsaw II technique students are more active than learning reading without using Jigsaw II technique. Through this technique developed by Slavin in 1986, students are invited to find information on a reading in groups. Then, students form expert groups according to the questions they get. Students must work on each other to get an outline and learn all the information because it will be tested individually.

The results of students' understanding then matched with the contents of the text through reading comprehension activities. This is different from the learning activities in the control class. The control class in this study used the conventional step in the learning process of reading comprehension, namely students receiving reading texts, reading, analyzing reading texts, and then concluding the reading contents. The different learning activities make the level of understanding from the both classes also different. The used of learning technique in interesting steps will affect students interests, motivation, and level of comprehension.

The difference in the learning process between the control class and the experiment class described above, affects the difference in students' reading comprehension abilities. This can be seen from the results of the Mann Whitney test after the control class and the experiment class with the help of the SPSS program, obtained by Asymp. $\mathrm{Sig}=0,000$. The $\mathrm{p}$ value is smaller than the significance level of $5 \%(0,000<0.05)$. In addition, there is also a difference in the acquisition of an average score after reading comprehension between the control class and the experiment class, that is, the Control Class $=70.33$ and the Experiment Class $=85.89$. Thus, it can be concluded that there are significant differences in reading comprehension skills between students who 
learned using Jigsaw II technique and students who learned without using Jigsaw II technique.

\section{The Effectiveness of Jigsaw II Technique in Reading Comprehension Learning in X Grade Students of SMK Negeri 1 Gombong}

The effectiveness of Jigsaw II technique in learning reading comprehension in X grade students of SMK Negeri 1 Gombong can be seen after the experiment class learned by used this technique. The gain score results obtained from the average post-test score minus the average pre-score score. The difference in the average score of pre-post-test in the experiment class was 23.78 while the change in the average score of pre-post-test in the control class was 6.11. The difference between the average pre-test scores in the experiment class was known to be more than in the control class $(23.78>6.11)$. The difference between the average pre-test scores of the experiment class was 23.78 obtained from the average post-test scores reduced by the average pre-test scores (85.89-62.11). The difference in the average score of pre-post-test in the control class only experienced a change of 6.11 , ie from the average post-test minus pre-test (70.3364.22). The difference in the increase in the average score of the experiment class more than the average score of the control class, showing that learning reading comprehension using Jigsaw II technique is more effective than learning reading comprehension without using Jigsaw II technique.

Based on the results of the Mann Whitney test, the analysis of pre-test and post-test reading comprehension and the difference in the increase of the average score in the experiment class with the control class, showed that the Jigsaw II technique proved to be effectively used in learning reading comprehension in class $\mathrm{X}$ students of SMK Negeri 1 Gombong. The experiment class that followed the learning reading comprehension using Jigsaw II technique had high motivation and enthusiasm when the learning process took place. These conditions affect the level of achievement of students' understanding of reading. Learning with Jigsaw II technique makes students do active interactions with the mind and the entire reading content. Therefore, students can achieve the goal of reading, which can understand the contents of the reading.

Based on the things that have been described above, it can be concluded that in reading comprehension learning technique were needed that can foster interest, motivation, and enthusiasm of students to think creatively and critically. Thus, students will have a concept of a good understanding of the reading content. Jigsaw II technique in learning reading comprehension is one alternative to overcome boredom in the learning process. Learning reading comprehension with Jigsaw II technique allows students to more easily understand the contents of reading texts, in addition, Jigsaw II technique are proven effective in learning reading comprehension.

\section{CONCLUSION}

Based on the results of research and discussion that has been explained previously, the following conclusions can be drawn. 
1. There is a significant difference in the ability in reading comprehension between students who learn in reading comprehension using Jigsaw II technique and those who did not.

This difference is evident from the Mann Whitney test conducted on post-test scores between the control class and the experiment class. From the Whitney Mann test results can be obtained asymp. Sig $=0,000$. The $\mathrm{p}$ value is smaller than the significance level of $5 \%(0,000<0.05)$. Thus, the results of the Mann Whitney test showed that there were significant differences in reading comprehension skills, between students who learn reading comprehension using Jigsaw II techniques and students who learned without using Jigsaw II techniques in X grade students of SMK Negeri 1 Gombong.

2. Jigsaw II technique has proven to be effective in learning reading comprehension in $\mathrm{X}$ grade students of SMK Negeri 1 Gombong.

This has proven by the difference in the results of the gain score test analysis. The difference in the effectiveness of the techniques used in the control class and experiment class can be seen based on the average increase in the pre-test and post-test scores of the control class and the experimental class. The result of the gain score reading comprehension of the control class was 6.11, while the experimental class was 23.78. The result of these calculations indicates a difference in the increase in the average value of pre-test and post-reading learning between the control class and the experiment class. The Increasing average score of the experimental class pre-post-test higher than the control class. This shows that the Jigsaw II technique is more effectively used in reading comprehension learning.

\section{REFERENCES}

Brown, H. Doughlas. (2001). Teaching by Principle: An Interactive Approach to Language Pedagogy. San Francisco State University: Longman.

Grabe, W. \& L. Stoller. F. (2011). Teaching and Researching Reading. Britain: Pearson Education.

Harvey, Michele. 2013. "Reading Comprehension: Strategies for Elementary and Secondary School Students”. Lynchburg College Journal of Special Education. Vol. 8. 2-15.

Koran Sindo. (2016, 14 Oktober). Education News Monitoring Service. Di unduh pada 3 September 2019, dari

https://acdpindonesia.wordpress.com/2016/10/14/reading-interest-of indonesianstudents-still-low/.

Mitsalin, E., \& Catur Pamungkas, A. (2021). Improving the Students' Participation In Speaking by Using Drilling Technique: A Classroom Action Research in the X Grade of SMK Ma'arif 1 Kebumen in the Academic Year 2019/2020. English 
Education and Literature Journal (E-Jou), 1(01), 24-34. https://doi.org/10.53863/ejou.v1i01.116

Nunan, D. (2003). Practical English Language Teaching. New York: McGraw-Hill Companies.

Nurgiyantoro, Burhan. (2013). Penilaian Pembelajaran Bahasa. Yogyakarta: BPFE.

Shaaban, Kassim. 2006. "An Initial Study of The Effects of Cooperative Learning on Reading Comprehension, Vocabulary Acquisition, And Motivation To Read." Reading Psychology, Vol. 27, hlm. 377-403.

Slavin. R. E. (1980). Cooperative Learning. Review of Educational Research. 50 (2). $315-342$.

Sugiyono. (2010). Metode Penelitian Pendidikan; PendekatanKuantitatif, Kualitatif, dan $R \& D$. Bandung: Alfabeta.

Yusup, F. (2018). Uji Validitas dan Reliabilitas Instrumen Penelitian Kuantitatif. Jurnal Tarbiyah Jurnal Ilmiah Kependidikan. 2 (2). 17-23 